\title{
Scientific Drilling in the Basin of Mexico to Evaluate Climate History, Hydrological Resources, and Seismic and Volcanic Hazards
}

\author{
by Erik T. Brown, Josef P. Werne, Socorro Lozano-García, Margarita Caballero, \\ Beatriz Ortega-Guerrero, Enrique Cabral-Cano, Blas L. Valero-Garces, \\ Antje Schwalb, and Alejandra Arciniega-Ceballos
}

doi:10.2204/iodp.sd.14.12.2012

\section{Introduction}

A group of fifty scientists and students from eight countries met on the campus of UNAM (Universidad Nacional Autónoma de México) in Mexico City on 4-8 March 2012 to plan for a program of continental drilling that will address a wide range of ongoing issues and hazards facing the Mexico City region. The initial impetus for the workshop was investigation of a long and continuous climate and ecological record preserved in the lake sediments underlying the city. Workshop attendees included participants with scientific interests in sediment core and borehole instrumentation in this region, including experts in volcanology, seismology, hydrology, geodesy and the associated geological hazards. The workshop was supported by the International Continental Scientific Drilling Program (ICDP) and UNAM.

The Basin of Mexico (Fig. 1; $9600 \mathrm{~km}^{2}, 2240 \mathrm{~m}$ asl) is a hydrologically closed basin in the central-eastern part of the Mexican Volcanic Belt. Active volcanism around this basin dates from the Oligocene to the present. The lake system of

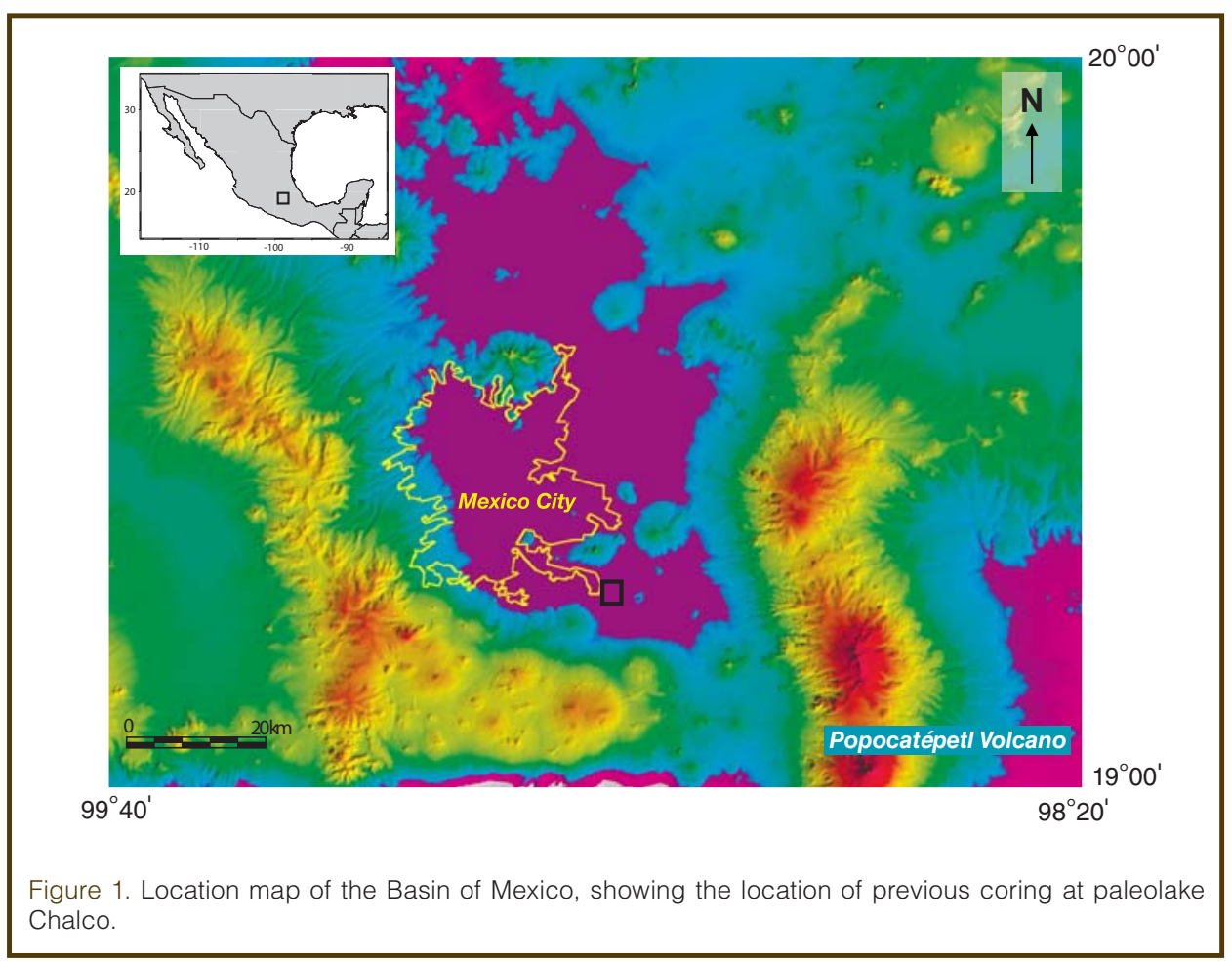

the basin may have developed an association with the basin's closure by emplacement of the Chichinautzin volcanic field in the southern sector of the basin after $780 \mathrm{ka}$ (Mooser et al., 1974; Urrutia-Fucugauchi and Martin del Pozzo, 1993). In any case, continuous deposition has allowed accumulation of thick sequences $(>400 \mathrm{~m}$ ) of lacustrine sediment interbedded with sporadic volcanic horizons.

The hydraulic regime of the former lakes of the Basin of Mexico has been modified since pre-Hispanic times for flood control and agricultural practices. Multiple efforts to drain the basin continued during colonial times in an effort to control periodic flooding and to foster urban development. Mexico City is built upon these lakebeds. Lake Chalco is located on the southernmost sector of the Basin of Mexico; due to its proximity to freshwater sources, Chalco has typically been less saline than other lakes within the basin. This lake was reduced to a small marsh during the nineteenth and early twentieth centuries. It is among the largest blocks of undeveloped agricultural land within the Mexico City megalopolis and is thus a prime target for scientific drilling.

Sediments from the Chalco Basin have the potential to yield a unique and remarkable record of climate history directly relevant to millions of people. An understanding of past variability in the regional hydrological regime, including variations in monsoonal precipitation, provides a basis for evaluation of ongoing climate change. In addition, the sediments can provide histories of volcanic activity, and their physical properties are relevant to models of seismic wave propagation in the basin as well as to understanding its intense subsidence and regional groundwater resources. Drilling for paleoenvironmental studies can be leveraged and complemented by continuous subsurface geophysical monitoring through instrumented boreholes that will provide additional insights 
into regional geologic hazards and better groundwater management.

\section{Climate and Ecological History}

A significant scientific objective of the Lake Chalco drilling will be obtaining a continuous, high-resolution record of past climates in the continental neotropics over the past $\sim 500 \mathrm{kyr}$. Previous studies at this location (Fig. 2) have exploited geochemical, geological, and ecological proxy records (Bradbury, 1989; Lozano-Garcia et al., 1993; LozanoGarcia and Ortega-Guerrero, 1994; Urrutia-Fucugauchi et al., 1994; Caballero-Miranda, 1997; LozanoGarcia and Xelhuantzi-Lopez, 1997; Caballero and Ortega Guerrero, 1998). This body of research demonstrates that Chalco sediments have the potential to provide unique knowledge of interannual through orbital-scale variations in the North American monsoon and the hydrological balance of the neotropics. Indeed, the cores we expect to retrieve from Chalco would be the longest continuous climate record from tropical North America, and therefore they could become the "type section" to which other records are compared. Southern North America is projected to become more arid in the coming decades and centuries in response to anthropogenically-driven climate change (Seager et al., 2007). In this already dry region, the increasing population pressures water supplies, so more intense drought may pose major societal challenges. Knowledge of past climate fluctuations will add to our understanding of ongoing climate change.

\section{Volcanic History and Hazard}

Volcanic activity has occurred throughout the Mexican Volcanic Belt since the Oligocene. For example, Popocatépetl, located at the southeastern end of the Basin of Mexico (35 km from Chalco), is regarded as one of Mexico's most dangerous volcanoes due to the massive eruptions (e.g., $23 \mathrm{ka}$ and $14 \mathrm{ka}$ ) preserved in the geological record (Siebe et al., 2004a, 2004b, 2005; Siebe and Macías, 2006; AranaSalinas et al., 2010). Popocatépetl resumed activity in 1994 after some sixty-five years of dormancy, and it presents a clear hazard to the region.

The drilling program serves needs in two areas.

1. Tephra layers preserved in sediments of the Chalco Basin will provide a unique record of eruptive histories. Precise dating of large and small eruptive events will help to refine the eruptive history from adjacent large stratovolcanoes and will aid in volcanic hazard prediction.

2. Installation of seismic motion sensors at depth will enable monitoring of seismic activity related to Popocatépetl's magma chamber and to aid in evaluating potential future eruptions. 


\section{Hydrological Resources and Subsidence}

Mexico City utilizes groundwater from its underlying lacustrine aquitard and aquifer. The fine-grained, organicrich Quaternary lacustrine sequences (Ortega-Guerrero et al., 1997) are highly susceptible to non-recoverable consolidation. Subsidence due to groundwater extraction in the Basin of Mexico was first recognized in the 1890s. In the subsequent 120 years this led to over ten meters of accumulated subsidence in downtown Mexico City, with accompanying damage to housing and urban infrastructure (Ovando-Shelley et al., 2007). During the 1950s subsidence was so widespread in the historic downtown area that extraction wells were relocated to outlying areas, including Chalco (Joint Academies Committee on the Mexico City Water Supply, 1995). In the Chalco region this led to the significant subsidence mentioned above, with current rates of $150-200 \mathrm{~mm} \mathrm{yr}^{-1}$. Continued withdrawal of groundwater and subsidence has stressed the upper lacustrine sequence, leading to surface fracturing (fracture lengths of $\sim 500 \mathrm{~m}$, with openings up to one meter and vertical displacement as much as two meters), most prevalent at the interface of lacustrine deposits with adjacent volcanic structures. A deep aquifer is also present within the Basin of Mexico; while it remains essentially unexploited, there is ongoing discussion of its potential to meet future needs of the growing city.

The Lake Chalco drilling project will serve multiple needs in this area.

1. physical characterization of sediments associated with aquifers and aquitards to improve understanding and modeling of subsidence, particularly including characterization of the deep (relatively unexploited) aquifer that has not been well-studied;

2. creation of master in situ and synthetic logs that can be used for stratigraphic correlation among boreholes within the basin (most of them for groundwater exploitation) and thus allow basin-wide, stratigraphic correlation; and

3. installation of permanent geodetic, hydrologic, and geotechnical monitoring and sampling instruments to characterize changes to groundwater in response to changing well water withdrawal.

\section{Seismic Risks}

Seismic hazards are omnipresent in Mexico City; the 1985 M 8.0 earthquake caused well over 10,000 casualties and considerable damage to city's buildings and infrastructure. Continuing activity (most recently, an M 7.4 event on 20 March 2012) poses an ongoing threat to the city. Recent tectonic research has focused on episodic tremor and slip (ETS) events in the Guerreo and Oaxaca segment of the
Mid-America trench (Brudzinksi et al., 2007). The subhorizontal geometry of the subducting slab underneath southern and central Mexico effectively widens the sesimogenic area and extends inland the occurrence of ETS events well into the Basin of Mexico.

This project serves two needs in this area: 1) Physical characterization of recovered core material will provide information needed to improve and refine geotechnical earthquake engineering models. 2) Installation of geodetic and seismic sensors-including collocated borehole strain meters, pore pressure sensors, deep seismic and tilt meters, and a surface GPS receiver-in deep boreholes will provide previously unavailable monitoring of micro-seismic activity isolated from surface noise.

\section{Workshop Outcomes}

We planned a scientific program that addresses the needs of studies of seismic hazards, volcanoes, hydrology, and paleoclimate/ecology. Prior geophysical studies provide a basis for a broad understanding of the geometry and depth of the basin, but they may be insufficient for selection of drill sites for core recovery. To address this, we are planning and coordinating efforts for magnetic, gravity, and passive seismic surveys to be undertaken in June and July 2012.

The plan is to undertake a two-phase drilling program (proposal to be submitted to ICDP in January 2013, so fieldwork could be as soon as 2014). Phase 1 will drill and log four 500-m wells suitable for use as instrumented boreholes for long-term monitoring of groundwater as well as seismic and volcanic activity. Downhole logs from Phase 1 (in combination with geophysical surveys) can be used to develop strategies for site selection for Phase 2 drilling. The second phase will recover a continuous sequence of core for the physical, chemical, biological, and geological characterization of sediments discussed above.

\section{References}

Arana-Salinas, L., Siebe, C., and Macías, J.L., 2010. Dynamics of the ca. 4965 yr 14C BP "Ochre Pumice" Plinian eruption of Popocatépetl volcano, México. J. Volcanol. Geoth. Res., 192:212-231, doi:10.1016/j.jvolgeores.2010.02.022

Bradbury, J.P., 1989. Late Quaternary lacustrine paleoenvironments in the Cuenca de Mexico. Quat. Sci. Rev., 8:75-100.

Brudzinski, M., Cabral-Cano, E., Correa-Mora, F., DeMets, C., and Márquez-Azúa, B., 2007. Slow slip transients along the Oaxaca subduction segment from 1993 to 2007. Geophys. J. Int., 171:523-538. doi: 10.1111/j.1365-246X.2007.03542

Caballero, M., and Ortega Guerrero, B., 1998. Lake levels since about 40,000 years ago at Lake Chalco, near Mexico City. Quat. Res., 50:69-79.

Caballero-Miranda, M., 1997. Reconstrucción paleolimnológica del Lago de Chalco durante el último máximo glaciar - El registro de diatomeas entre 34,000 y 15,000 años A.P. Rev. Mex.. Cienc. Geol., 14:91-100. 
Herrera-Hernández D., 2011. Estratigrafía y análisis de facies de los sedimentos lacustres del Cuaternario tardío de la cuenca de Chalco, México. MSc Thesis, Posgrado en Ciencias de la Tierra, Instituto de Geofísica, Universidad Nacional Autónoma de México. 122 pp.

Joint Academies Committee on the Mexico City Water Supply, 1995. Mexico City's Water Supply: Improving the Outlook for Sustainability: Washington, DC (National Academy Press), $230 \mathrm{pp}$.

Lozano-Garcia, M.S., and Ortega-Guerrero, B., 1994. Palynological and magnetic susceptibility records of Lake Chalco, central Mexico. Palaeogeogr. Palaeoclim. Palaeoecol., 109:177-191.

Lozano-Garcia, M.S., and Xelhuantzi-Lopez, M.S., 1997. Some problems in the Late Quaternary pollen records of central Mexico basins of Mexico and Zacapu. Quat. Int., 43:117-123.

Lozano-Garcia, M.S., Ortega-Guerrero, B., Caballero-Miranda, M., and Urrutia-Fucugauchi, J., 1993. Late Pleistocene and Holocene paleoenvironments of Chalco Lake, Central Mexico. Quat. Res., 40:332-342.

Mooser, F., Nairn, A.E.M., and Negendank, J.F.W., 1974. Palaeomagnetic investigations of the tertiary and quaternary igneous rocks: VIII a palaeomagnetic and petrologic study of volcanics of the valley of Mexico. Geol. Rundsch., 63:451-483, doi:10.1007/BF01820824

Ortega-Guerrero, A., Cherry, J., Aravena, R., 1997. Origin of pore water and salinity in the lacustrine aquitard overlying the regional aquifer of Mexico City. J. Hydrology, 197:47-69, doi:10.1016/S0022-1694(96)03280-5

Ovando-Shelley, E., Ossa, A., and Romo, M.P., 2007. The sinking of Mexico City: Its effects on soil properties and seismic response. Soil Dynam. Earthquake Eng., 27:333-343, doi:10.1016/j.soildyn.2006.08.005

Seager, R., Ting, M., Held, I., Kushnir, Y., Lu, J., Vecchi, G., Huang, H., et al., 2007. Model projections of an imminent transition to a more arid climate in southwestern North America. Science, 316:1181-1184.

Siebe, C., and Macías, J.L., 2006. Volcanic hazards in the Mexico City metropolitan area from eruptions at Popocatépetl, Nevado de Toluca, and Jocotitlán stratovolcanoes and monogenetic scoria cones in the Sierra Chichinautzin volcanic field. In Siebe, C., Macías, J.L., Aguirre, G. (Eds.), NeogeneQuaternary Continental Margin Volcanism. A Perspective from Mexico: Geol. Soc. Am. Spec. Pub., 402:253-329, doi:10.1130/2004.VHITMC.SP402

Siebe, C., Arana-Salinas, L., and Abrams, M., 2005. Geology and radiocarbon ages of Tláloc, Tlacotenco, Cuauhtzin, Hijo del Cuauhtzin, Teuhtli, and Ocusacayo monogenetic volcanoes in the central part of the Sierra Chichinautzin, México. J. Volcanol. Geoth. Res., 141:225-243, doi:10.1130/2004. VHITMC.SP402

Siebe, C., Rodríguez-Lara, V., Schaaf, P., and Abrams, M., 2004a. Geochemistry, Sr-Nd isotope composition, and tectonic setting of Holocene Pelado, Guespalapa and Chichinautzin scoria cones, south of Mexico City. J. Volcanol. Geoth. Res., 130:197-226, doi:10.1016/S0377-0273(03)00289-0

Siebe, C., Rodríguez-Lara, V., Schaaf, P., and Abrams, M., 2004b. Radiocarbon ages of Holocene Pelado, Guespalapa, and Chichinautzin scoria cones, south of Mexico City: Implications for archaeology and future hazards. Bull.
Volcanol., 66:203-225, doi:10.1007/s00445-003-0304-Z

Urrutia-Fucugauchi, J., and Martin del Pozzo, A.L., 1993. Implicaciones de los datos paleomagneticos sobre la edad de la Sierra de Chichinautzin, Cuenca de Mexico. Geofisica Internacional, 32:523-533.

Urrutia-Fucugauchi, J., Lozano, S., Ortega-Guerrero, B., Caballero, M., Hansen, R., Bohnel, 1994. Paleomagnetic and paleoenvironmental studies in the southern basin of Mexico, Geofis. Int., 33:421-444.

\section{Authors}

Erik T. Brown and Josef P. Werne, Large Lakes Observatory and Department of Geological Sciences, University of Minnesota Duluth, 2205 East 5 th Street, Duluth, MN 55812-3024, U.S.A., e-mail: etbrown@d.umn.edu

Socorro Lozano-García, Instituto de Geología, Universidad Nacional Autónoma de México, Cd. Universitaria, 04510 México D.F., México

Margarita Caballero, Beatriz Ortega-Guerrero, Enrique Cabral-Cano, and Alejandra Arcniega-Ceballos, Instituto de Geofísica, Universidad Nacional Autónoma de México, Cd. Universitaria, 04510 México D.F., México

Blas L. Valero-Garces, Instituto Pirenaico de Ecologia Consejo Superior de Investigaciones Cientificas, E-50080 Zaragoza, Spain

Antje Schwalb, Institut für Geosysteme und Bioindikation Technische, Universität Braunschweig, D-38106 Braunschweig, Germany 